\title{
Edukacja międzykulturowa w przedszkolu - raport z badań nauczycieli
}

\begin{abstract}
STRESZCZENIE
Autorka w artykule zwraca uwagę na włączanie treści z zakresu edukacji międzykulturowej do wychowania przedszkolnego oraz przywołuje, przynoszące pozytywne rezultaty, przykłady działań nauczycieli w tym zakresie. Formułuje i empirycznie weryfikuje tezę, że realizacja edukacji międzykulturowej w przedszkolu pozytywnie oddziałuje na rozwój kompetencji społecznych dzieci, poprawne stosunki z rówieśnikami, rozbudza u dziecka chęć poznawania siebie i Innych.
\end{abstract}

\section{Słowa kluczowe:}

edukacja międzykulturowa, przedszkole, edukacja małego dziecka

\begin{abstract}
In the article the author stresses importance of including intercultural education content into kindergarten education and presents examples of positive results brought by teachers' actions in this field. The author formulates and empirically verifies the thesis that implementation of intercultural education in kindergarten positively affects the development of social competences of children, improves their relations with peers and arouses in a child the will to get to know himself/herself and others.
\end{abstract}

\section{Keywords:}

intercultural education, kindergarten, young child's education

1 Anna Twardzik, Wydział Etnologii i Nauk o Edukacji, Uniwersytet Śląski w Katowicach, Polska, anna.twardzik@us.edu.pl. 


\section{WPROWADZENIE}

Już w drugiej połowie XX w. Nicolai Hartmann, zauważył, że coraz częściej mamy do czynienia ze zjawiskiem 'przesunięcia horyzontu aksjologicznego jednostek' (Hartmann, 1974). Jego myśl jest nadal aktualna i urzeczywistnia się na wielu płaszczyznach życia. W społeczeństwie wiedzy ważne staje się propagowanie wartości poznawczych oraz kreowanie postawy „Mieć”. Wynika to ze zmiennych warunków bytowych, w których żyje jednostka, z faktu, że pomiędzy tymi samymi wartościami zachodzą określone związki oraz zmiany postrzegania wartości, które z czasem powszednieją (Ogrodzka-Mazur, 2013). Efektem tego jest między innymi rozluźnienie więzi społecznych, trudności w nawiązywaniu relacji/kontaktów z drugim człowiekiem oraz nadmierny indywidualizm i egocentryzm.

Świadomość inności - jak zauważa Jerzy Nikitorowicz (2007, s. 108) - przekształca się w obcość dopiero wtedy, gdy pojawiają się emocje i postawy łączące się z pojawiającą różnicą, wzbudzającą lęk, strach i agresję. Niewiedza i stereotypy są powodem budzącej się agresji wobec inności. Badania empiryczne wskazują na to, że negatywny stosunek innych ludzi przejawiają już dzieci trzyletnie (negatywny stosunek do ludzi starszych), a dzieci w wieku od 7-13 lat posiadają uprzedzenia wobec różnych grup społecznych (Młynarczyk - Sokołowska, 2012, s. 132). Na każdym kroku spotykamy się z ksenofobią oraz agresją wobec odmienności. Warto zastanowić się zatem nad tym, co powinna zrobić w tym zakresie edukacja.

Środowiska naukowe pewne nadzieje wiążą z edukacją międzykulturową, przez którą według Danuty Markowskiej (1990, s. 109) „należy rozumieć proces oświatowo-wychowawczy, którego celem jest kształtowanie rozumienia odmienności kulturowych (...)” . Jak twierdzi Alina Szczurek-Boruta (2006, s. 37) „edukacja realizuje jednocześnie dwa sprzeczne zadania polegające na przygotowaniu młodego pokolenia do otwartości wobec Innych i ich kultur, przy jednoczesnym zachowaniu własnej tożsamości, autonomii i indywidualizmu. Podstawą realizacji edukacji międzykulturowej - zdaniem tej autorki - jest uczenie się budowania pozytywnych relacji z drugim człowiekiem oraz uświadamianie sobie różnic i podobieństw pomiędzy ludźmi”.

W niniejszym artykule zwracam uwagę na włączanie treści z zakresu edukacji międzykulturowej do wychowania przedszkolnego oraz przywołuję, przynoszące pozytywne rezultaty, przykłady działań nauczycieli w tym zakresie. Formułuję i empirycznie weryfikuje tezę, że realizacja edukacji międzykulturowej w przedszkolu pozytywnie oddziałuje na rozwój kompetencji społecznych dzieci, poprawne stosunki z rówieśnikami, rozbudza u dziecka chęć poznawania siebie i Innych. 


\section{ROZWÓJ I EDUKACJA DZIECKA W WIEKU PRZEDSZKOLNYM - POTRZEBY I MOŻLIWOŚCI WŁĄCZANIA TREŚCI Z ZAKRESU EDUKACJ MIĘDZYKULTUROWEJ DO WYCHOWANIA PRZEDSZKOLNEGO}

Badania z zakresu psychologii rozwojowej i edukacji małego dziecka prowadzone przez m.in. Annę Brzezińską (2000), H. Rudolpha Schaffera (2006) czy Ann Brich (2012) wskazują na to, że dziecko na etapie wychowania przedszkolnego (2,5-7 lat) rozwija się bardzo intensywnie (rozwój społeczny, kształtowanie więzi i nawiązywaniem relacji rówieśniczych).

Już na tym etapie zaczynają pojawiać się u niego potrzeby afiliacji i uznania najbliższego otoczenia, w tym przede wszystkim rówieśników. Adaptacja do nowych warunków, konieczność zaakceptowania reguł, a także uczenie się funkcjonowania w grupie - współbycie i współdziałanie z rówieśnikami podczas zajęć i zabawy stają się kluczowe dla tego etapu. Jest to bez wątpienia okres, kiedy dziecko coraz intensywniej zaczyna obcować z ludźmi pochodzącymi z różnych środowisk. W psychologii rozwojowej wiek od 4-7 lat to czas kształtowania umiejętności dostrzegania odmienności, zauważania innych ras odmienności etnicznych (Bryant, Dolman, 1997). Wczesne i stopniowe przybliżanie dziecku kwestii związanych z odmiennością tworzy ważny poznawczo fundament do współdziałania z Innymi (Młynarczuk-Sokołowska, Szostak-Król, 2012, s. 133).

Istotny jest również sposób myślenia dziecka w wieku przedszkolnym. Według Jeana Piageta dziecko jest w tym okresie na etapie przedoperacyjnym rozwoju poznawczego, co jest powodem poznawania świata za pomocą symboli. Przekłada się to na sposób postrzegania i rozumienia zachodzących wokół niego zjawisk. Egocentryzm typowy dla tego wieku skutkuje trudnościami w nawiązywaniu kontaktów z innymi osobami oraz negatywizmem w relacjach z otoczeniem (Schaffer, 2014).

Wszystko to przemawia za tym, by już na tym etapie uczyć dziecko, w jaki sposób nawiązywać poprawne relacje z drugim człowiekiem, ale też kształtować odpowiednie postawy, które pomogłyby mu w przyszłości tworzyć stałe związki, pozytywne kontakty interpersonalne oraz efektywnie współpracować w zespole.

Wspomóc ten proces może niewątpliwie edukacja międzykulturowa, która ma duże znaczenie w doskonaleniu umiejętności społecznych małego dziecka, a także w jego uspołecznieniu. Można w tym miejscu odwołać się do holistycznej koncepcji edukacji międzykulturowej Jerzego Nikitorowicza (2007), której kluczową kategorią jest uwrażliwianie kulturowe na wartości w zakresie trzech kręgów: dziedzictwa kulturowego (edukacja regionalna), innych kultur i ich reprezentantów (edukacja wielokulturowa) oraz relacji międzyludzkich (edukacja 
międzykulturowa). Na etapie wychowania przedszkolnego dziecko powinno nauczyć się szacunku do zróżnicowania, rozwinąć gotowość do uczenia od reprezentantów innych kultur, nabyć wiedzę o nich, by współistnieć i przezwyciężać stereotypy (Suchodolska, 2011, s. 52). Ważne staje się przeciwdziałanie nieuzasadnionym uprzedzeniom przez organizowanie zajęć umożliwiających doświadczanie i tworzenie pozytywnych wyobrażeń na temat Innych (Kamińska, 2007). Dziecko w wieku przedszkolnym buduje pierwsze autonomiczne więzi z Innymi. Inni stają się ważni, bo za ich pośrednictwem dziecko uczy się we wspólnej przestrzeni, weryfikuje swoje emocje i doświadcza nowych (Suchodolska, 2011, s. 52).

Dla małego dziecka istotne jest poznanie najbliższego otoczenia, uwrażliwianie na inność drugiego człowieka oraz rozwijanie współpracy i współdziałania w wielu obszarach życia. Edukacja międzykulturowa w przedszkolu powinna być realizowana rzetelnie przez wszystkich nauczycieli. W wielu placówkach przedszkolnych funkcjonują grupy zróżnicowane kulturowo (zróżnicowanie wyznaniowe, rasowe, etniczne, pod względem płci czy stopnia sprawności ruchowej lub intelektualnej) (pojęcie przyjmuję za Młynarczuk-Sokołowską, 2016, s.174-187). Nieliczni nauczyciele zdają sobie z sprawę z tego, że funkcjonowanie dziecka w takiej grupie bardzo często wiąże się z wieloma trudnościami i nieporozumieniami. W skrajnych przypadkach możemy mówić nawet o agresji rówieśniczej i przemocy fizycznej lub emocjonalnej. W moim przekonaniu treści z zakresu edukacji międzykulturowej powinny być stałym elementem programu wychowania przedszkolnego.

Nowa Podstawa programowa wychowania przedszkolnego wyraźnie podkreśla, jak ważne jest kształtowanie u dziecka wrażliwości na drugiego człowieka (Rozporządzenie MEN z 14.02.17 w sprawie podstawy wychowania przedszkolnego, s. 2; 5). W wyodrębnionych zadaniach rozwoju społecznego akcentuje kształtowanie poczucia własnej wartości, wyrażanie szacunku wobec innych osób i przestrzeganie tych wartości, a także, co jest istotne nawiązywanie prawidłowych relacji rówieśniczych. Kwestie te i zagadnienia mieszczą się w obszarze działań z zakresu edukacji międzykulturowej. Ich wprowadzanie i realizacja w przedszkolu jest potrzebna i bardzo ważna, wynika zarówno z potrzeb rozwojowych dzieci w wieku przedszkolnym, jak i potrzeb społecznych m.in. kształtowania relacji $\mathrm{z}$ drugim człowiekiem, z otoczeniem. 


\section{METODOLOGIA BADAŃ}

Celem podjętych poczynań badawczych było poznanie sposobów realizacji edukacji międzykulturowej przez nauczycieli wychowania przedszkolnego oraz określenie efektów tych działań.

W badaniach zastosowano podejście ilościowo-jakościowe. Strategię ilościową i jakościową zastosowano jako wręcz komplementarne względem siebie (Pilch, Bauman, 2001, Rubacha 2008). W ramach badań ilościowych przeprowadzono badanie online (Siuda, 2016), natomiast w badaniach jakościowych posłużono się obserwacją etnograficzną w wybranych przedszkolach.

W badaniach wzięło udział łącznie 124 nauczycieli wychowania przedszkolnego (38 nauczycieli dyplomowanych, 43 mianowanych, 26 kontraktowych, 17 stażystów) pracujących zarówno w placówkach publicznych, jak i niepublicznych na terenie całej Polski. Dobór grupy badanej był celowy (Babbie, 2005, s. 205). Wszyscy nauczyciele biorący udział w badaniach należą do istniejących na portalu społecznościowym grup dyskusyjnych m.in. „Multicultural teacher”, „Wielokulturowy świat w przedszkolu” oraz prowadzą działania z edukacji międzykulturowej w przedszkolu (warunek uczestniczenia w badaniu). Grupy zostały utworzone z własnej inicjatywy nauczycieli na potrzeby praktyki edukacyjnej w zakresie edukacji międzykulturowej.

W badaniach zastosowano ankietę internetową (pojęcie przyjmuję za: Piotr Siuda, 2016) typu II (kwestionariusze umieszczone na stronach zamkniętych; Bradley, 2006). Kwestionariusz ankiety zawierał 20 pytań, wśród nich były pytania otwarte oraz zamknięte z pięciostopniową skalą Likerta - kategorie odpowiedzi: zdecydowanie tak, raczej tak, trudno powiedzieć, raczej nie, nie (Rubacha, 2008, s. 175). Pytania dotyczyły tego, w jaki sposób nauczyciele w przedszkolu realizują treści edukacji międzykulturowej oraz czy prowadzone działania w ich opiniach przynoszą pozytywne rezultaty (widoczne m.in. w kontaktach rówieśniczych pomiędzy dziećmi).

W ramach badań jakościowych posłużono się obserwacją etnograficzną. Jej celem jest zbieranie „(...) danych poprzez bezpośredni udział badacza w naturalnym środowisku społecznym” (Pilch, Bauman, 2008, s.85). Obserwacja została przeprowadzona w pięciu przedszkolach (grupy przedszkolne prowadzili nauczyciele należący do wskazanych grup społecznościowych), w wybranych grupach i trwały od 3 do 5 dni w każdej placówce. We wszystkich placówkach prowadzono dziennik obserwacji oraz dokumentację fotograficzną. Głównymi kategoriami obserwacji były: częstotliwość prowadzenia i różnorodność zajęć z edukacji międzykulturowej, sposób zachowania dzieci/relacje pomiędzy nimi (podejmowanie 
współpracy, konfliktowość, umiejętność pracy w zespole), zachowanie nauczyciela (pozytywne, życzliwe nastawienie do uczniów), stosunek dzieci do prowadzonych zajęć (zadowolenie z zajęć, aktywne uczestnictwo). W niniejszym artykule opisano tylko wybrane kategorie - częstotliwość prowadzenia zajęć z edukacji międzykulturowej, stosunek dzieci do tych zajęć oraz relacje pomiędzy dziećmi.

Do analizy zebranego materiału ilościowego posłużono się metodą statystyki opisowej, z kolei do analizy danych jakościowych zastosowano metodę redukcji danych - kodowanie rzeczowe oraz teoretyczne (Rubacha, 2008, s. 203-271).

\section{PREZENTACJA WYNIKÓW BADAŃ I DYSKUSJA}

Nauczyciele, którzy wzięli udział w badaniach realizują treści edukacji międzykulturowej w przedszkolu. Zdaniem większości respondentów (98 osób) wprowadzanie treści międzykulturowych w przedszkolu jest potrzebne, zaledwie 12 nauczycieli nie było pewnych, czy podejmowanie takich inicjatyw ma sens odpowiedzi: „trudno powiedzieć”, „raczej nie”). Szczegółowe dane przedstawia wykres nr 1.

Potrzebę prowadzenia zajęć z edukacji międzykulturowej wśród małych dzieci badani uzasadniają, wskazując na wartości i cele tej edukacji. Świadczą o tym poniższe wybrane wypowiedzi nauczycieli:

„Współczesne dziecko powinno być wychowywane na obywatela świata” (nauczyciel kontraktowy, kobieta, staż pracy 3 lata, Białystok).

„Przedszkole to miejsce, w którym dziecko powinno nauczyć się żyć w zgodzie z samym sobą, ale też z otaczającym je światem” (nauczyciel dyplomowany, kobieta, staż pracy 20 lat, Bielsko-Biała).

„Jeżeli chcemy, aby nasz świat w przyszłości był «dobry» powinniśmy uczyć dzieci szacunku, pokazywać, że różnorodność jest piękna. Nikt nie powinien i nie jest taki sam. To jest wspaniałe” (nauczyciel mianowany, kobieta, staż pracy 12 lat, Wrocław).

Działania nauczycieli w tym zakresie są bardzo zróżnicowane. Badani realizują wiele projektów o tematyce międzykulturowej (m.in.: „Mały Europejczyk, „Ja i inni”, „Kolorowe dzieci”, Projekt e-twinningowy - „Maya the Bee travels around the world”, „Bajki świata”). Celem tych projektów jest poznanie inności drugiego człowieka, doskonalenie umiejętności nawiązywania pozytywnych relacji oraz zapoznanie się z inną kulturą. 


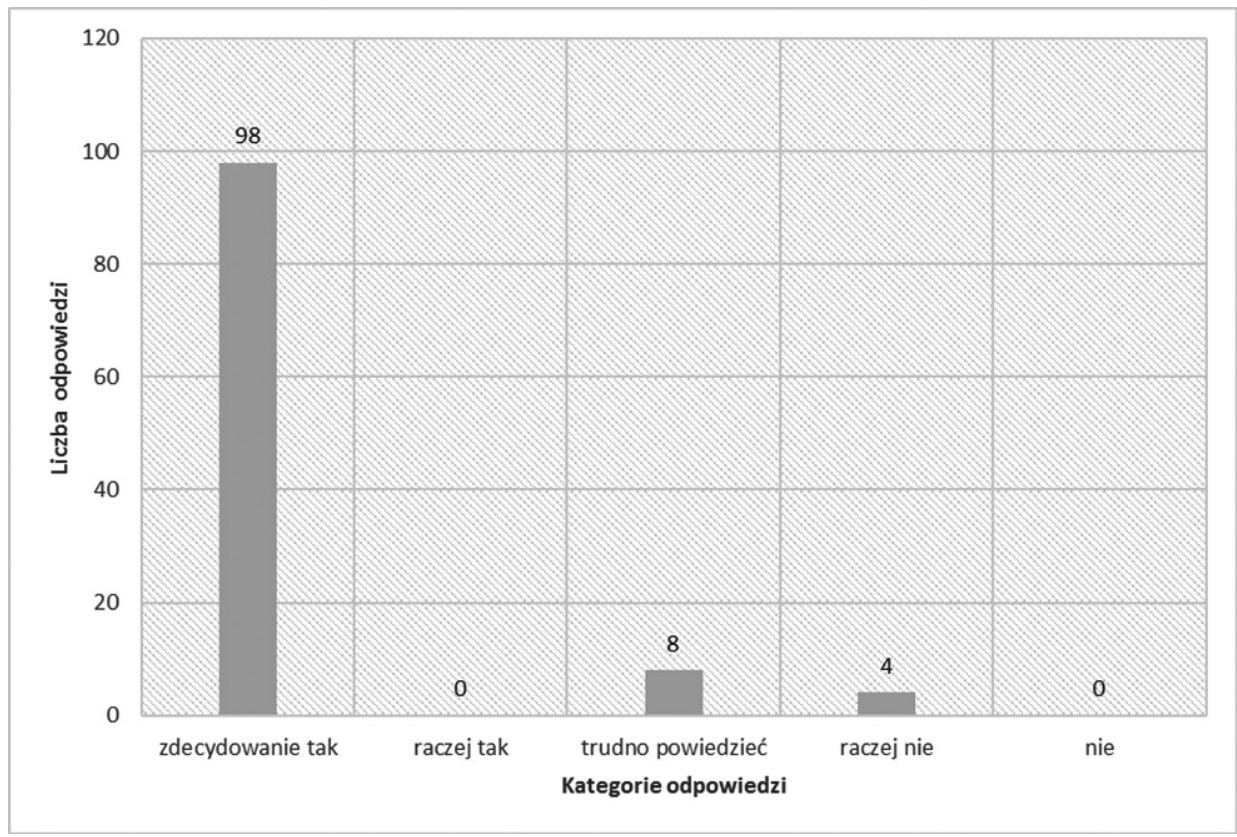

Wykres 1. Deklaracje nauczycieli dotyczące wprowadzania treści międzykulturowych w przedszkolu Źródło: opracowanie własne.

Nauczyciele dostrzegają pozytywne rezultaty podejmowanych działań. Zauważają, że dzieci stały się bardziej ciekawe świata, interesują się tym, co dzieje się wokół nich, a przede wszystkim rozwinęły umiejętności społeczne, co przekłada się na relacje z rówieśnikami. Fakt ten ilustrują poniższe wypowiedzi nauczycieli:

„Moja grupa z wielkim zainteresowaniem brała udział w realizacji programu. Szczególnym zainteresowaniem cieszyły się zajęcia kulinarne, na których dzieci poznawały specjały pochodzące z obcych krajów” (nauczyciel kontaktowy, kobieta, staż pracy 5 lat, Olsztyn).

„Dzieci chętnie brały udział w zajęciach. Zauważyłam, że poprawiły się relacje pomiędzy nimi w grupie. Mniej się kłócą, więcej współpracują (...)” (nauczyciel mianowany, kobieta, staż pracy 12 lat, Bielsko-Biała).

Edukacja międzykulturowa realizowana w przedszkolu dostosowana jest do możliwości poznawczych dziecka, sposobu rozumienia świata, postrzegania drugiego człowieka, myślenia na poziomie operacji konkretnych. Działania nauczycieli aktywizują dzieci. Część nauczycieli stosuje np. metodę „odwróconej lekcji” (autor nieznany, 2017). Dzieci włączają się w organizację zajęć, 
przynoszą do przedszkola informacje na dany temat przygotowane wcześniej z rodzicami (m.in. zdjęcia przedstawiające zabytki danego kraju, charakterystyczne zwierzęta, produkty do przygotowania określonych potraw). Świadczą o tym wyniki przeprowadzonych obserwacji zajęć, ale też wypowiedzi nauczycieli udzielone $\mathrm{w}$ ankiecie. Nauczyciele włączają treści edukacji międzykulturowej do zajęć tematycznych (Dzień Babci i Dziadka, Międzynarodowy Dzień Dziecka, Dzień Kropki, Święta Bożego Narodzenia, Wielkanoc, Światowy Dzień Ziemi), prowadzą zajęcia integracyjne (dla dzieci, rodziców i dziadków) oraz uczestniczą w projektach e-twinningowych, które cieszą się coraz większym zainteresowaniem.

Zajęcia o tematyce międzykulturowej inspirowane są głównie zainteresowaniami dzieci (deklaracje większości nauczycieli - 72 osób, wykres 2) i bieżącymi potrzebami (program nauczania, wymogi dyrekcji, własny program autorski).

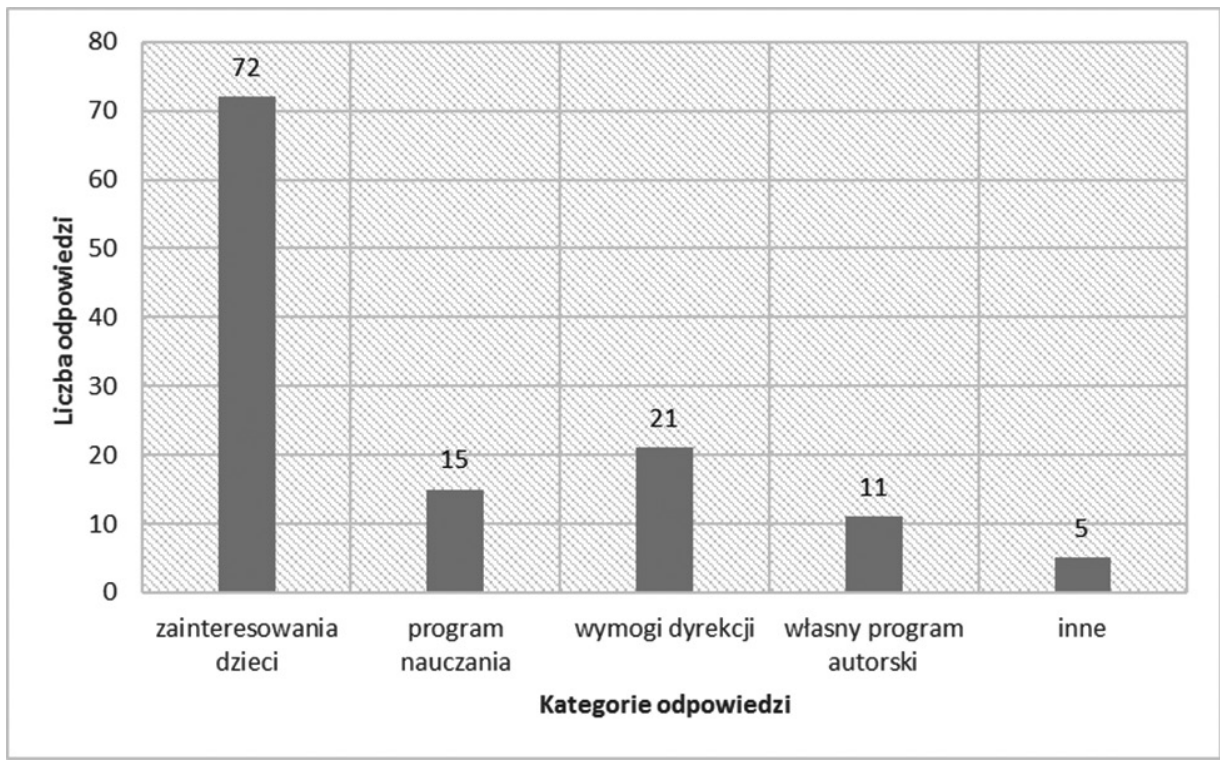

Wykres 2. Deklaracje nauczycieli dotyczące, tego czym są inspirowane zajęcia w zakresie edukacji międzykulturowej

Źródło: opracowanie własne.

Nauczyciele deklarują, że w swojej pracy stosują także „bajki międzykulturowe”. „Bajka międzykulturowa jest utworem skierowanym do dzieci, którego zadaniem jest uwrażliwianie ich na istniejące różnice pomiędzy ludźmi we wszystkich 
zakresach funkcjonowania człowieka: biologicznym, ekonomicznym, społecznym i kulturowym, które są permanentnie wpisane w każdą rzeczywistość społeczną” (Młynarczuk-Sokołowska, Szostak-Król, 2012, s. 137). Ta forma pracy i uwrażliwiania kulturowego jest odpowiednia do możliwości percepcyjnych dzieci wieku przedszkolnym. Odpowiednio dobrane treści umożliwiają dzieciom zrozumienie nawet najtrudniejszych zagadnień. Nauczyciele w swojej pracy wykorzystują bajki zawarte w takich pracach jak: Przygody Innego (Młynarczuk-Sokołowska, 2011), Spotkania z Innymi. Czytanki do edukacji międzykulturowej (Grzybowski, 2011), Elmer (McKee, 2011), Bajki o misiach z czterech stron świata (Cholewińska-Szkolik, 2011), Baśnie z czterech stron świata (Sobich, 2013).

Badani dostrzegają pozytywne efekty swoich działań: ciekawość, chęć poznania Innego, otwartość dzieci, osłabianie stereotypów, nabywanie nowej wiedzy, doskonalenie umiejętności społecznych, nawiązywanie współpracy.

Wyniki badań ilościowych przeprowadzonych wśród nauczycieli dopełniły przeprowadzone obserwacje etnograficzne. Ich przedmiotem były takie kategorie jak: częstotliwość prowadzenia i różnorodność zajęć z edukacji międzykulturowej, stosunek dzieci do prowadzonych zajęć (zadowolenie z zajęć, aktywne uczestnictwo) oraz relacje pomiędzy dziećmi). W przedszkolach, w których prowadzono badania, nauczyciele z wielkim zaangażowaniem inicjują działania w zakresie edukacji międzykulturowej. Są one realizowane podczas codziennych zajęć edukacyjnych wynikających z podstawy programowej, przybierają formę dygresji, opowiadań, zabaw lub ćwiczeń, a także w trakcie zajęć tematycznych. Zauważyć można, że nauczyciele aktywnie włączają dzieci do różnych działań grupowych, które mają na celu uczenie współpracy i współdziałania. W grupach przedszkolnych biorących udział w badaniu średnio dwa razy dziennie nauczyciele prowadzili ćwiczenia grupowe lub zabawy w grupach. Większość dzieci chętnie i aktywnie uczestniczyła w proponowanych zajęciach. Sporadycznie zdarzały się przypadki, że dzieci niechętnie chciały włączać się do zabawy grupowej.

W czasie zajęć np. dotyczących poznawania kultury innego kraju nauczyciele w badanych grupach przedszkolnych często integrują muzykę, plastykę, zabawy ruchowe czy zajęcia kulinarne. Jest to dla dzieci bardzo ciekawe, a zarazem daje możliwość lepszego przyswojenia prezentowanych treści. Ciekawą propozycją, powszechną wśród wielu nauczycieli było stosowanie gier dydaktycznych, w czasie których dzieci miały możliwość uczyć się od siebie nawzajem, co rozwijało umiejętności współdziałania i współpracy. Popularne są również „kąciki tematyczne”, tj. np. Kącik Małego Podróżnika, gdzie umieszczone były przedmioty związane z danym krajem i okresowo były one wymieniane w zależności od omawianych na bieżąco treści. 
Relacje pomiędzy nauczycielami a wychowankami oparte są na zasadzie partnerstwa i podmiotowości w każdej z badanych grup. Mimo, iż były to dzieci w wieku przedszkolnym nauczyciele liczyli się z ich zdaniem - m.in. pytali o kwestie dotyczące zajęć czy podejmowanych aktywności. Aktywnie włączali dzieci w proces edukacji, a przez to podkreślali ich podmiotowość. Poniżej przedstawiam odnotowane podczas obserwacji wypowiedzi nauczycieli obrazujące omawiane kwestie:

„Czy podobają Wam się takie zajęcia?” (nauczyciel wychowania przedszkolnego, nauczyciel kontraktowy, Bielsko-Biała)

„Lubicie pracować w małych grupach?” (nauczyciel wychowania przedszkolnego, nauczyciel dyplomowany, Sosnowiec).

„O czym chcielibyście jutro ze mną porozmawiać?” (nauczyciel wychowania przedszkolnego, Czechowice-Dziedzice).

„Zauważyliście co umieściłam w Kąciku Podróżnika? Może macie w domach jakieś pamiątki z podróży, które chcielibyście pokazać innym dzieciom i opowiedzieć o nich? (...)” (nauczyciel wychowania przedszkolnego, nauczyciel mianowany, Bielsko- Biała).

Wyniki przeprowadzonych badań wskazują na to, że systematycznie prowadzone działania z edukacji międzykulturowej w przedszkolu oddziałują pozytywnie na rozwój społeczny dzieci oraz na relacje rówieśnicze w grupie. Efektywność tego typu działań potwierdzają wyniki eksperymentu prowadzonego przez Martę Guzik-Tkacz i Dorotę Pakuła-Tamou (2016).

Działania podejmowane przez nauczycieli są dla dzieci atrakcyjne i bardzo efektywne. Ich celem jest uwrażliwianie dzieci na drugiego człowieka oraz uczenie współpracy. Prezentowane praktyki pedagogiczne w zakresie edukacji międzykulturowej wpisują się w ten zakres i spełniają postawione cele.

\section{KONKLUZJE}

W opracowaniu tym przywołałam przykłady działań włączających idee międzykulturowości do praktyki wychowania przedszkolnego. Wyniki badań własnych wskazują na to, że nauczyciele wychowania przedszkolnego dostrzegają korzyści wynikające z prowadzenia takich zajęć: uczenie współpracy, współdziałania, kształtowanie pozytywnej postawy wobec drugiego człowieka. Zdaniem Aliny Szczurek- Boruty (2013, s. 61) ,uczenie się w kontaktach międzyludzkich i uwraż- 
liwianie kulturowe $\mathrm{w}$ bezpośrednim kontakcie z innością to istotne warunki nie tylko do kształtowania się tożsamości ludzi świadomych siebie, swoich możliwości, ale i warunki integracji społecznej”.

Prowadzenie edukacji międzykulturowej w przedszkolu wymaga odpowiedniego przygotowania nauczycieli, by w sposób naturalny wprowadzać treści międzykulturowe do zabawy, nauki i pracy dziecka. Warto, aby nauczyciele zweryfikowali swe działania pod kątem tego, czy kształtują u dziecka umiejętności, które pozwolą mu funkcjonować w społeczeństwie zróżnicowanym społecznie i kulturowo.

\section{Bibliografia}

Autor nieznany. Odwrócona lekcja - wprowadzenie. Pobrane z: http://www.ceo.org.pl/pl/ cyfrowaakademia/news/odwrocona-lekcja-wprowadzenie.

Babbie, E. (2005). Badania społeczne w praktyce (przeł. m.in W. Berkiewicz, M. Bucholc; red. naukowa A. Kloskowska-Dudzińska). Warszawa: Wyd. Naukowe PWN.

Birch, A. (2012). Psychologia rozwojowa w zarysie. (tł. J. Łuczyński, M. Olejnik). Warszawa: Wyd. PWN.

Bradley, N. (2006). Sampling for Internet Surveys. An examination of respondent selection for Internet research. Pobrane z http://users.wmin.ac.uk/ bradlen/papers/sam06.html.

Bryant, P., Dolman, A. (1997). Psychologia rozwojowa. Poznań: Wyd. Zysk i S-ka.

Brzezińska, A (2000). Społeczna psychologia rozwoju. Warszawa: Wyd. Naukowe „Scholar”.

Cholewińska-Szkolik, A. (2011). Bajki o misiach z czterech stron świata. Book Home.

Grzybowski, P.P. (2011). Spotkania z Innymi. Czytanki do edukacji międzykulturowej. Kraków: Oficyna Wydawnicza „Impuls”.

Grzybowski, P.P. (2007): Edukacja europejska - od wielokulturowości ku międzykulturowości. Kraków: Oficyna Wydawnicza „Impuls”.

Guziuk-Tkacz, M., Pakuła-Tomau D. (2016). Transkulturowe dzieci (eksperyment przedszkolny). W: J. Nikitorowicz, A. Młynarczuk-Sokołowska, U. Namiotko (red.), Edukacja w warunkach wielokulturowości - Konteksty społeczno-metodyczne. Gdańsk: Wydawnictwo Naukowe „Katedra”.

Hartmann, N. (1974). Najważniejsze problemy etyki. Tłum. A. Węgrzecki. Znak, 11.

Kamińska, K. (2007). Nauczyciel wychowania przedszkolnego wobec wielokulturowości. Łódź: Wyd. UŁ.

Łobocki, M. (1992). Wprowadzenie do metodologii badań pedagogicznych. Kraków: Oficyna Wydawnicza „Impuls”.

Markowska, D. (1990). Teoretyczne podstawy edukacji międzykulturowej. Kwartalnik Pedagogiczny, 4.

McKee, D. (2011). Elmer. Warszawa: Papilon.

Młynarczuk-Sokołowska, A. (2016). Praca z grupq zróżnicowanq kulturowo- wybrane 
zagadnienia. W: J. Nikitorowicz, A. Młynarczuk-Sokołowska, U. Namiotko (red.), Edukacja w warunkach wielokulturowości - Konteksty społeczno-metodyczne (s. 174-187). Gdańsk: Wydawnictwo Naukowe „Katedra”.

Młynarczuk-Sokołowska, A., Szostak-Król, K. (2012). Bajki międzykulturowe - w poszukiwaniu rozwiązań metodycznych w obszarze edukacji międzykulturowej dzieci w wieku przedszkolnym i wczesnoszkolnym. Edukacja Międzykulturowa, 1, s. 132.

Młynarczuk-Sokołowska, A. (2011). Przygody Innego. Bajki w edukacji międzykulturowej. Białystok: Fundacja Edukacji i Twórczości w Białymstoku.

Młynarczuk-Sokołowska, A., Szostak-Król, K. (2012). Bajki międzykulturowe - w poszukiwaniu rozwiązań metodycznych w obszarze edukacji międzykulturowej dzieci w wieku przedszkolnym i wczesnoszkolnym. Edukacja Międzykulturowa, 1, s. 133.

Nikitorowicz, J. (2007). Edukacja międzykulturowa. Kreowanie tożsamości dziecka. Gdańsk: GWP.

Ogrodzka-Mazur, E. (2013). (Nie)obecność patriotyzmu w świadomości aksjologicznej Polaków. „Przesunięcie się horyzontu aksjologicznego” czy kryzys w wartościowaniu? W: J. Nikitorowicz (red.), Patriotyzm i nacjonalizm. Ku jakiej tożsamości kulturowej? (s. 112-113). Kraków: Oficyna Wydawnicza „Impuls”.

Pilch, T., Bauman T. (2008). Zasady badań pedagogicznych. Strategie ilościowe i jakościowe. Warszawa: Wyd. Naukowe Scholar.

Rozporządzenie MEN z 14.02.2017 w sprawie podstawy programowej wychowania przedszkolnego oraz podstawy programowej kształcenia ogólnego dla szkoły podstawowej, w tym dla uczniów z niepełnosprawnością intelektualną w stopniu umiarkowanym lub znacznym, kształcenia ogólnego dla branżowej szkoły I stopnia, kształcenia ogólnego dla szkoły specjalnej przysposabiającej do pracy oraz kształcenia ogólnego dla szkoły policealnej, Załącznik 1 - Podstawa programowa wychowania przedszkolnego dla przedszkoli, oddziałów przedszkolnych w szkołach podstawowych oraz innych form wychowania przedszkolnego.

Rubacha, K. (2008). Metodologia badań nad edukacjq. Warszawa: Wyd. i Profesjonalne. Schaffer, H.R. (2014). Psychologia rozwoju dziecka. Tłum. A. Wojciechowski, red. nauk. A. Brzezińska. Warszawa: PWN.

Schaffer, H.R. (2002). Rozwój społeczny. Dzieciństwo i młodość. Kraków: Wyd. Uniwersytetu Jagiellońskiego.

Siuda P. (2016). Ankieta internetowa: zalety i wady - rekapitulacja. W: P. Siuda (red.), Metody badań online (s. 28-29). Bydgoszcz: Wydawnictwo Naukowe Katedra.

Sobich A. (2013). Baśnie z czterech stron świata. Warszawa: Papilon.

Suchodolska, J. (2011). Poznajemy Innego i jego kulturę oraz kształtujemy tolerancję. W: T. Lewowicki, J. Suchodolska (red.), Dzieci w procesie kształtowanie postaw kulturowych. Przewodnik po ścieżkach edukacji regionalnej, wieloi międzykulturowej (s. 13-19). Kraków: Oficyna Wydawnicza „Impuls”.

Szczurek-Boruta, A. (2006). Tożsamość i jej szerszy kontekst instytucjonalny - o przydatności teorii strukturalizacji Anthony’ego Giddensa dla teorii i praktyki edukacji międzykulturowej. W: T. Lewowicki, A. Szczurek -Boruta, E. Ogrodzka-Mazur 
(red), Teorie i modele badań międzykulturowych (s. 31-40). Cieszyn-Wrocław: Wyd. UŚ.

Szczurek-Boruta, A. (2013). Doświadczenia społeczne w przygotowaniu przyszłych nauczycieli do pracy w warunkach wielokulturowości. Toruń: Wyd. Adam Marszałek. Wygotski, L.S. (2002). Wybrane prace psychologiczne II. Dzieciństwo i dorastanie. Poznań: Wyd. Zysk i S-ka. 